\title{
PENGOLAHAN CISTIK SUKUN DI DESA MERTASINGA KECAMATAN CILACAP UTARA
}

\section{THE ARTUCARPUS ALTILIS SNACK PROCESSING IN MERTASINGA VILLAGE, NORTH CILACAP SUB DISCRICT}

\author{
${ }^{1)}$ Tri Watiningsih, ${ }^{2)}$ Tjahjani Mirdijaningsih ${ }^{3)}$ Reni Sulistiyowati, AM \\ ${ }^{1)}$ Program Studi Teknik Elektro, ${ }^{2}$ ) Program Studi Teknik Sipil,Fakultas Teknik \\ ${ }^{3)}$ Program Studi Akuntansi' Fakultas Ekonomi, Universitas Wijayakusuma Purwokerto \\ 1)email: tri_cadipa@yahoo.com
}

\begin{abstract}
ABSTRAK
Tujuan dari kegiatan ini adalah: 1) Memberikan pengetahuan teoritis kepada Produsen Cistik Sukun di Desa Mertasinga dan Desa Tritih Wetan Kecamatan Cilacap Utara tentang bagaimana membuat dan mengemas hasil produksi yang baik 2) Meningkatan Mutu hasil olahan sukun di Desa Mertasingan dan Desa Tritih Wetan Kecamatan Cilacap Utara untuk mengolah sukun dengan sentuhan teknologi dan Sains 3) Memperkuat produsen cistik sukundi Desa Mertasingan dan Desa Tritih Wetan Kecamatan Cilacap Utaramenjadi masyarakat yang mandiri secara ekonomi.Kegiatan ini terdiri dari pemberian pengetahuan tentang pengolahan sukun agar lebih menarik dan mendapatkan nilai jual yang baik, pelatihan pembuatan cistik sukun dan pengemasan, pelatihan pembuatan anggaran dalam penjualan, evaluasi, pameran hasildan pendampingan. Sedangkan metode yang digunakan dalam kegiatan ini dalah ceramah, pemberian pelatihan, demonstrasi, simulasi pembuatan cistik sukun.Target luaran kegiatan ini berupa:1) Media pembelajaran pengetahuan bagi produsen cistik sukun, 2). Pengetahuan tentang pengemasan cistik sukun agar lebih menarik dan mendapatakan harga jual yang tinggi,3). Bermanfaat bagi masyarakat khususnya produsen cistik sukun menjadi masyarakat yang mandiri secara ekonomi.
\end{abstract}

Keyward :Sukun, Pengolahan, Cistik, Pengemasan. Pemasaran Sukun

\begin{abstract}
The purposeof this activity are: 1) To provide theoretical knowledge to the "Cistik" Breadfruit producer in Mertasinga and Tritih Wetan vistage, North Cilacap sub district in foodprocessing and packaging 2) To increase the quality ofbreadfruit in Mertasingan and Tritih Wetan village by using technology and Science approahe3) Cistik breacfruit producent stregtring in Mertasingan and Tritih Wetan vistage, Nort Cilacap Utara Sub distrik to be economically self sufficient communities .This activities are consistan of processing supervision, packaging, food production training,budgeting, produc tevaluation, exhibitions hasildan assistance. While the methods that we used are lecturing, foad training, demonstrations, and simulations. The resuls are "Cistik" breadfruit, hand book, final food packaging and marketing tecknique for societies..
\end{abstract}

Keyward: Breadfruit, Processing, Cistik, Packaging, Markerting

Submited : 15 September 2016 Revisied : 10 Nopember 2016 Accepted : 21 Januari 2017

\section{PENDAHULUAN}

Sukun memiliki nama latin Artocarpus altilis dan termasuk dalam keluarga Moraceae. Buah sukun mempunyai kemiripan dengan buah durian dan buah nangka.Terutama pada bagian kulitnya yang terlihat berduri. Namun duri kulit buah sukun lebih tumpul dibanding durian maupun nangka. Daging buah sukun sangat empuk sehingga orang 
inggris menyebutnya sebagai buah roti. Di Indonesia sendiri buah sukun sering dijadikan camilan seperti keripik atau direbus. Sementara buahnya yang masih muda biasa dijadikan sayur.

Sukun sudah lama dikenal di tengah masyarakat Indonesia.Buahnya biasa digoreng dibuat keripik, atau direbus sebagai makanan kecil. Harganya yang tidak mahal menjadikannya makanan kecil yang banyak dijajakan.Buah sukun (tak berbiji) merupakan bahan pangan penting sumber karbohidrat di pelbagai kepulauan di daerah tropik, terutama di Pasifik dan Asia Tenggara. Sukun dapat dimasak utuh atau dipotong-potong terlebih dulu: direbus, digoreng, disangrai atau dibakar. Buah yang telah dimasak dapat diiris-iris dan dikeringkan di bawah matahari atau dalam tungku, sehingga awet dan dapat disimpan lama. (Widowati, 2003)

Di pulau-pulau Pasifik, kelebihan panen buah sukun akan dipendam dalam lubang tanah dan dibiarkan berfermentasi beberapa minggu lamanya, sehingga berubah menjadi pasta mirip keju yang awet, bergizi dan dapat dibuat menjadi semacam kue panggang. Sukun dapat pula dijadikan keripik dengan cara diiris tipis dan digoreng.Sukun dapat menghasilkan buah hingga 200 buah per pohon per tahun. Masing-masing buah beratnya antara 400-1200 gr, namun ada pula varietas yang buahnya mencapai 5 kg.Nilai energinya antara 470-670 kJ per 100 gram. Tidak mengherankan bila sukun menarik minat para penjelajah Barat, yang kemudian mengimpor tanaman ini dari Tahiti ke Amerika tropis (Karibia) pada sekitar akhir 1780an untuk menghasilkan makanan murah bagi para budak di sana.(Pitojo, 1992).

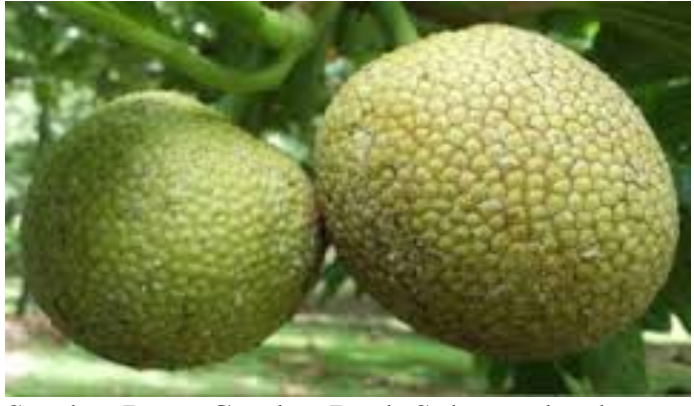

Sumber Data: Gambar Buah Sukun gelondong yang belum dikupas

\section{Kandungan Gizi Buah Sukun}

Jumlah per Porsi

$\begin{array}{rr} & \text { dari } \\ \text { Kalori } 103 & \text { Lemak } \\ 1.80\end{array}$

\begin{tabular}{|l|r|}
\hline \multicolumn{1}{|c|}{} & \% Nilai harian \\
\hline Total Lemak 0.20 g & $0.3 \%$ \\
\hline \hline Lemak Jenuh 0.100 g & $0.5 \%$ \\
\hline Kolesterol 0 mg & $0.0 \%$ \\
\hline Sodium 2 mg & $0.1 \%$ \\
\hline Total Karbohidrat 27.10g & $9.0 \%$ \\
\hline \hline Diet Serat 4.9 g & $19.6 \%$ \\
\hline Protein 1.10 g & $2.2 \%$ \\
\hline \hline & \\
\hline \hline Vitamin C & $48.3 \%$ \\
\hline \hline Vitamin B1 Thiamin & $6.0 \%$ \\
\hline \hline Vitamin B2 Riboflavin & $1.8 \%$ \\
\hline \hline Vitamin B3 Niasin & $4.0 \%$ \\
\hline \hline Vitamin B5 Asam Pantotenat acid & $5.6 \%$ \\
\hline \hline Vitamin B6 & $15.0 \%$ \\
\hline \hline Kalsium & $1.7 \%$ \\
\hline \hline Besi & $2.8 \%$ \\
\hline \hline Kalium & $14.0 \%$ \\
\hline \hline Fosfor & $3.0 \%$ \\
\hline \hline Magnesium & $6.3 \%$ \\
\hline \hline Seng & $0.7 \%$ \\
\hline \hline Tembaga & $4.0 \%$ \\
\hline \hline Mangan & $3.0 \%$ \\
\hline \hline C Sistein & $1.7 \%$ \\
\hline \hline F Fenilalanin & $3.0 \%$ \\
\hline \hline I Isoleusin & $4.6 \%$ \\
\hline \hline K Lisin & $1.8 \%$ \\
\hline \hline L Leusin & $1.9 \%$ \\
\hline \hline M Metionin & \\
\hline & \\
\hline
\end{tabular}




\begin{tabular}{|l|r|}
\hline T Treonin & $5.0 \%$ \\
\hline \hline Tirosin & $2.2 \%$ \\
\hline \hline V Valin & $2.6 \%$ \\
\hline \hline W Triptofan & $10.7 \%$ \\
\hline
\end{tabular}

* Nilai Persen harian berdasarkan diet 2.000 kalori. Nilai harian Anda mungkin lebih tinggi atau lebih rendah tergantung pada kebutuhan kalori Anda.

\begin{tabular}{|l|l|}
\hline Jumlah total lemak & Kurang dari $65 \mathrm{~g}$ \\
\hline \hline Lemak jenuh & Kurang dari $20 \mathrm{~g}$ \\
\hline Kolesterol & Kurang dari 300mg \\
\hline Sodium & Kurang dari 2,400mg \\
\hline Jumlah Karbohidrat & $300 \mathrm{~g}$ \\
\hline Diet Serat & $25 \mathrm{~g}$ \\
\hline
\end{tabular}

Departemen Pertanian. (2003).

Program Ipteks bagi Masyarakat (IbM) Universitas Wijayakusuma Purwokerto diperuntukkan Kelompok tani Produsen sukun di Mertasinga Cilacap Utara akan merampungkan dua pokok agenda kegiatan diantaranya pengolahan Cistik sukun dan Sriping sukun. Program ini bertujuan untuk produsen cistik sukun dengan mengangkat serta memberdayakan potensi desa untuk dikembangkan sebagai wirausaha sehingga bernilai komersial.

Pelaksanaan program diperuntukkan bagi kalangan ibu-ibu yang tidak bekerja .Hal ini untuk membantu ibu-ibu dalam penambahan penghasilan ekonomi keluarga, juga menggalakkan pengolahan cistik sukun. Selain diberikan penyuluhan juga diberi bekal pengetahuan mengenai pembuatan dan pengolahan cistik sukun menjadi produk bernilai ekonomis. Mitra dalam kegiatan ini adalah Petani sukun di Desa Mertasinga Cilacap Utara dengan tiap kelompok berjumlah 5 orang.Mereka adalah ibu-ibu kelompok produsen sukun cistik yang mempunyai waktu luang disamping mngurus rumah, suami dan anak. Mereka menginginkan mencari nafkah tambahan untuk meringankan beban suami dengan bekerja di rumah setelah pekerjaan rumah tangganya selesai dikerjakan.
Dengan kreatifitasnya para ibu bisa mengolah buah sukun menjadi makanan khas cilacap yang lebih bernilai ekonomis .Diharapkan dengan keunggulan cistik dari bahan sukun,dapat meningkatkan kreatifitas dan motivasipara ibu-ibu, dan dapat membantu ibu-ibu dalam penambahan penghasilan ekonomi keluarganya.

Permasalahan yang mendapat prioritas yang harus ditangani adalah:

1. Pengadaan sarana dan prasarana penunjang aktivitas produksi Sarana dan prasarana perlu diberikan untuk menunjang operasionalisasi kegiatan swadaya dan pengelolaannya pun harus berdasarkan kesepakatan kelompok produsenSukun Desa Mertasinga.

2. Publikasi produk lewat media elektronik dan media massa

3. Menjalin relasi dengan Dinas Pertanian selaku instansi terkait dan dengan sumber-sumber pemasok dana atau donatur yang dapat membantu kelancaran usaha masyarakat kecil seperti koperasi, bank pembangunan daerah dan kaum pemilik modal/investor.

4. Menghimpun kerjasama dengan instansi terkait dan tenaga penyuluh untuk membina dan memberdayakan warga masyarakat Desa Mertasinga dengan memberikan bekal pengetahuan dan keterampilan.

5. Menemukan cara untuk mengkoordinir warga masyarakat untuk dimintakan kesediaannya diikutkan dalam kegiatan pelatihan yang dilakukan oleh tenaga ahli dari Jurusan PKK

6. Mencari solusi dalam pengadaan $\mathrm{P} 2 \mathrm{M}$ kerjasama antara Perguruan Tinggi dengan tenaga penyuluh dari Dinas Pertanian Kecamatan 
7. Merancang jasa pelayanan berupa marketing programme yang bersifat transparan.

8. Diversifikasi produk dari segi alih fungsi teknologi bargi hasil studi komparatif dengan desa Mertasinga, dan hasil pembinaan dari P2M ,kerjasama antara Perguruan Tinggi dengan Dinas Pertanian Kecamatan

9. Sistem panen yang relatif tinggi membutuhkan pengalokasian hasil panen yang tepat, dengan pembinaan P2M diharapkan dapat menjadikan produsen sukun berswadaya, swakarsa dan swasembada dalam meningkatkan taraf kesejahteraan mereka.

10.Sistem packing dengan standar dari BPOM dapat menarik minat konsumen untuk merasa aman dan nyaman mengkonsumsi hasil produk diversifikasi pangan dan hal itu dapat dibuktikan dengan sistem pemasaran yang lancar dan memasyarakat

\section{METODE}

Kelompok sasaran pengabdian pada masyarakat adalah Kelompok produsen cistik sukun Desa Mertasinga Kecamatan Cilacap Utara Kabupaten Cilacap. Salah satu warga masyarakat dari kelompok produsensukun tersebut adalah Hartono sebagai perintis usaha pengolahan sukun yang sifatnya personal dengan mempekerjakan 5 orang karyawan.Hasil olahannya baru sebatas Cistik Sukun, untuk limbah sukun yang berupa kulit belum diproduktifkan keberadaannya hanya sebatas sebagai pakan ternak.

Berdasarkan gambaran dari potret permasalahan yang dihadapi mitra, tolok ukur transfer iptek bagi masyarakat adalah dengan menyasar 20 Ibu PKK sebagai perwakilan masing-masing dusun di desa
Mertasinga untuk dilatih dalam hal pengolahan bahan sukun menjadi produk usaha industri rumah tangga yang sifatnya swadaya dengan pemberdayaan warga masyarakat masing-masing dusun yang ditunjuk berdasarkan hasil musyawarah oleh Kepala Desa beserta staf dengan tindak lanjut koordinasi kegiatan oleh bagian Kesra desa Mertasinga, tim pelaksana IbM Universitas Wijayakusuma Purwokerto

Program ini merupakan program yang bersifat aktual dalam rangka peningkatan pengetahuan dan wawasan Ibu PKK di Desa Mertasinga Kecamaan Cilacap Utaracara pengolahan sukun sebagai komoditas produksi dengan langkah sosialisasi dan pelatihan. Untuk kepentingan pencapaian tujuan program ini, maka rancangan yang dipandang sesuai untuk dikembangkan adalah "RRA dan PRA" (rural rapid appraisal dan participant rapid appraisal). Di dalam pelaksanaannya, program ini akan mengacu pada pola sinergis antara tenaga pakar dan praktisi dari Universitas Wijayakusuma dengan kalangan birokrasi dan administrasi pemerintah desa Mertasinga Kecamatan Cilacap Utara, khususnya pihak Pemerintah Desa Metasinga dan Ibu-Ibu PKK desa Mertasinga. Di sisi lain, program ini juga diarahkan pada terciptanya iklim kerjasama yag kolaboratif dan demokratis dalam dimensi mutualis antara dunia perguruan tinggi dengan masyarakat secara luas di bawah koordinasi pemerintah desa setempat, khususnya dalam rangka meningkatkan pengetahuan dan wawasan generasi Ibu PKK desa Mertasinga Kecamatan Cilacap Utara secara cepat namun berkualitas bagi kepentingan pembangunan masyarakat setempat. Berdasarkan rasional tersebut, maka program ini merupakan sebuah langkah inovatif dalam kaitannya dengan Tri Dharma perguruan tinggi, yaitu salah 
satunya adalah pengabdian kepada masyarakat.

\section{HASIL DAN PEMBAHASAN}

Kegiatan telah dilaksanakan yaitu: sosialisasi dan pelatihan produksi olahan industri rumah tangga berbahan baku Sukun, manajemen pembukuan produksi, dan pengurusan ijin usaha perdagangan. Hal yang masih berlangsung sampai saat ini adalah pendampingan kelompok dalam hal manajemen produksi dan pengurusan ijin usaha perdagangan.

Sesuai dengan permasalahan yang dihadapi oleh warga masyarakat desa Mertasinga Kecamatan Cilacap Utara dalam kaitannya dengan upaya pengembangan wawasan pengetahuan dan keterampilan pengolahan sukun menjadi hasil produksi rumah tangga, maka program pengabdian masyarakat ini dilakukan dalam bentuk transfer iptek yang dilakukan berupa sosialisasi, pelatihan, dan pendampingan kepada Ibu PKK desa Mertasinga yang akan mengolah hasil perkebunan Sukun yang semula hasil pendapatan petani sukun hanya terbatas pada penjualan sukun glondong, dikembangkan melalui pembekalan wawasan pengetahuan dan keterampilan praktik tata boga, penyusunan pembukuan sederhana, dan tata cara pengurusan ijin usaha sehingga harapan terakhir program Ibu PKK yang dilatihkan dapat diproduktifkan kinerjanya dalam usaha produksi rumahan yang sifatnya sambilan dengan mengolah hasil pertanian kebun sukun menjadi beraneka ragam jenis produk camilan yang sifatnya inovatif untuk membuka lapangan pekerjaan baru dalam menunjang pemasukan kebutuhan seharihari.

$\begin{array}{ccr}\text { Untuk } & \text { mengukur tingkat } \\ \text { keberhasilan kegiatan yang telah }\end{array}$

dilakukan, maka akan dilakukan evaluasi minimal 3 (tiga) kali, yaitu evaluasi proses, evaluasi akhir, dan evaluasi tindak lanjut. Kegiatan evaluasi ini melibatkan tutor/pakar dari Unwiku Purwokerto. Kriteria dan indikator pencapaian tujuan dan tolak ukur yang digunakan untuk menjastifikasi tingkat keberhasilan kegiatan.

. Sosialisasi dan pelatihan pembukuan yang tim pelaksana selenggarakan bertujuan untuk menunjang tingkat pengetahuan dan wawasan Ibu-ibu PKK yang mayoritas adalah istri petani sukun untuk bisa memiliki bekal manajemen usaha berupa pembukuan sederhana arus pengeluaran dan pemasukan apabila suatu saat mereka dapat merintis kegiatan usaha yang dikembangkan setelah mendapatkan sosialisasi dan pelatihan.

Prosedur dan tata cara pengurusan ijin juga dilatihkan kepada Ibu PKK untuk memberikan bekal tentang pengurusan ijin usaha baik yang sifatnya individu maupun kelompok dari Ibu PKK. Pengurusan ijin penting karena nantinya Ibu PKK dapat menggunakan SIUP yang dimiliki sebagai agunan simpan pinjam di BKK maupun BRI terdekat di tingkat Kecamatan.

Hal ini dapat dilihat dari hasil diskusi dan evaluasi yang dilakukan oleh tim pelaksana IbM Unwiku, terhadap pengetahuan dan keterampilan peserta sosialisasi dan pelatihan. Berdasarkan evaluasi tindak lanjut yang dilakukan, ditemukan bahwa Ibu PKK di Desa Mertasinga yang mengikuti pelaksanaan program memiliki pengetahuan yang konsisten mengenai keterampilan pengolahan makanan, keterampilan penyusunan pembukuan, dan keterampilan tentang tata cara pengurusan ijin usaha. Dengan demikian, sesuai dengan kriteria keberhasilan program, maka sosialisasi dan pelatihan ini dinilai berhasil apabila mampu meningkatkan 
pengetahuan dan wawasan peserta yang dalam hal ini menyasar Ibu PKK.

Berdasarkan hasil evaluasi tidak lanjut juga terekam, beberapa manfaat praktis yang diperoleh oleh Ibu PKK Desa Mertasinga Kecamatan Cilacap tara melalui sosialisasi dan Pelatihan Tata Boga, Pembukuan, Prosedur dan Tata Cara Pengurusan Ijin Usaha, yaitu:

1. Mereka mendapatkan informasi yang jelas dan utuh mengenai hakekat pemberdayaan masyarakat dari segi pengetahuan dan keterampilan, bermakna untuk penciptaan lapangan pekerjaan baru yang sifatnya inovatif dari pengembangan industri rumah tanggga dari Ibu PKK.

2. Ibu PKK yang menjadi peserta pelatihan memperoleh gambaran yang jelas mengenai langkah pengembangan iklim usaha dengan memanfaatkan komoditas jambu mete secara swadaya.

3. Peserta pelatihan juga mendapatkan gambaran yang jelas dan utuh tentang manfaat hasil perkebunan sukun apabila dikelola dengan baik..

Kendala pelaksanaan program adalah sulitnya mengatur waktu untuk pencapaian kesepakatan pelaksanaan kegiatan, karena umumnya peserta latihan terbentur dengan rutinitas pekerjaan harian yang menunjang perekonomian keluarga, pada umumnya. Jadi, untuk bisa mengkoordinir warga perlu koordinasi intensif dengan pihak kesra dan segenap jajarannya. Berkaitan dengan pengkondisian peserta program, walaupun dijumpai kendala masalah waktu selama tim pelaksana program mampu mengatasinya dengan melakukan koordinasi secara intensif dengan Kepala Desa Mertasinga, staf Kesra desa Mertasinga. Kubu yang pada saat tahap evaluasi kegiatan memfasilitasi tim pelaksana dari segi tempat yang berupa aula Dinas Pertanian untuk dimanfaatkan sebagai tempat uji coba untuk melakukan praktek evaluasi hasil pelaksanaan kegiatan.

Untuk evaluasi hasil produk telah mampu dibuat secara mandiri oleh warga olahan industri rumah tangga berbahan baku sukun dengan pendampingan dari tim pelaksana program. Untuk manajemen pembukuan sudah jalan dan untuk pengurusan ijin usaha selama ini masih dalam proses menunggu kegiatan usaha tersebut dikembangkan menjadi kegiatan usaha mandiri maupun berkelompok. Jadi, baik manajemen pembukuan maupun ijin usaha pada tahapan pelaksanaan program juga sudah terealisasi namun perlu evaluasi pada program tahap lanjutan karena harus menunggu jenis usaha yang akan dikelola oleh warga tentunya yang mendasarkan pada pengembangan usaha industri rumah tangga berbasis pemberdayaan buah sukun.

Pelaksanaan studi komparatif telah dilakukan untuk mengukur kinerja program dengan tingkat ketercapaian hasil sasaran dari peserta. Hasil perbandingan tampak sekali bahwa desa sidanegara lebih produktif warganya dalam mengelola hasil buah sukun dibandingkan dengan desa Mertasinga yang baru sifanya rintisan sehingga program pendampingan berupa sosialisasi dan pelatihan IbM Pengolahan sukun sangat tepat menyasar kebutuhan warga desa Mertasinga kecamatan Cilacap Utara.

Tindak lanjut yang harus dilakukan adalah tetap melakukan koordinasi dan pemantauan mengenai perkembangan hasil pelatihan yang telah dikembangkan warga, dan sewaktu-waktu tim pelaksana akan melakukan peninjauan ke lapangan untuk mengukur tingkat ketercapaian program yang telah terlaksana. Koordinasinya tetap melibatkan kerjasama antara LPPM, tim 
pelaksana IbM Pengolahann Sukun, Pemerintah Desa Mertasinga termasuk berbagi pengalaman dari petani sukun yang dinilai sukses mengelola usaha dengan bahan dasar olahan Sukun.

\section{SIMPULAN}

Tingkat partisipasi yang tinggi dari mitra program pengabdian kepada masyarakat memberikan dampak positif bagi pelaksanaan program, terlihat dari pelatihan dan pendampingan tata boga berbahan baku Sukun, manajemen produksi, dan tata cara pengurusan ijin usaha perdagangan dapat berjalan dengan baik Pelaksanaan program mampu menghasilkan luaran-luaran yang diharapkan oleh program pengabdian kepada masyarakat ini, kecuali surat ijin usaha perdagangan "kelompok PKK" masih harus diurus karena jenis usaha kelompok yang akan dikelola masih dalam taraf rintisan untuk dikembangkan sehingga perlu tahapan-tahapan administrasi melalui proses pendaftaran yang harus dipenuhi dan disepakati secara kolektif antar pengurus terlebih dahulu. Termasuk marketing pogramm terkait jenis produk yang ditawarkan di pasar belum disepakati oleh kelompok mengenai varian produk dari olahan berbasis industri rumah tangga yang akan dikelola dan dipasarkan.

\section{DAFTAR PUSTAKA}

Pitojo. S. (1992). Budidaya Sukun. Penerbit Kanisius : Yogyakarta

Widowati, S. (2003). Prospek Tepung Sukun Untuk Berbagai Produk Makanan Olahan Dalam Upaya Menunjang Diversifikasi Pangan. http://tumotou.net/70207134

/sri_widowati.htm 